\title{
Sistematização do Conhecimento Agroflorestal na Cooperafloresta (Barra do Turvo), Estado de São Paulo.
}

\author{
Victor Salek Bosso (IC), Maristela Simões do Carmo (PQ).
}

\section{Resumo}

Este trabalho apresenta um novo aporte metodológico para compreensão e auxílio à tomada de decisão no planejamento e manejo de Sistemas Agroflorestais (SAFs), que é o fator determinante de um SAF. Foca-se nas propostas de Götsch, que são sistemas altamente densos, biodiversos, multiestratificados. Elas embasam-se em diferentes conceitos e visões como a Pesquisa-Ação, Percepção Ambiental e a Extensão como Processo Educativo. Constitui uma abordagem mais holística que busca entender os argumentos e as lógicas que sustentam as decisões de agricultores e técnicos para o estabelecimento de SAFs, ou seja, quais parâmetros ambientais são considerados nas decisões do planejamento e do manejo de SAFs e como o saber ecológico dos agricultores podem relacioná-los.

Palavras Chave: Planejamento e Manejo de Agroforestas, Sistematização do Conhecimento, Observação Participante.

\section{Introdução}

Agroflorestas ou Sistemas Agroflorestais (SAFs) são uma ótima opção de sistema produtivo do ponto de vista ambiental, social e econômico. Ainda assim, as agroflorestas não são amplamente difundidas. Além disso, não há muitos estudos sobre os problemas na adoção dos SAFs e ademais, os agricultores agroflorestais estão dispersos geograficamente, dificultando a troca de conhecimentos e sua sistematização ${ }^{1}$.

Não há receita para o manejo agroflorestal. A prática agroflorestal baseia-se no conhecimento e na percepção da dinâmica ecológica. $O$ fato de não haver receitas, entretanto, não pode ser pretexto para não se implantar uma agrofloresta por falta de método?

A Cooperafloresta é uma referência de agroflorestas bem-sucedidas por quase 20 anos.

\section{Resultados e Discussão}

O conhecimento Agroflorestal que foi colhido junto aos agricultores e técnicos por meio de entrevistas semi-estruturadas e da observação participante $^{3}$ realizada em práticas de implantação e manejo de agroflorestas além da literatura foi todo sistematizado em mapas mentais $^{4}$ (Figura 1). Confeccionou-se ainda um mapa das variáveis e indicadores do planejamento e manejo e outro das atividades práticas da implantação e do manejo agroflorestal. Um ponto observado é a dificuldade e/ou resistência de muitos agricultores à prática da poda, em especial de frutíferas, o que reduz a produção e até a vida das mesmas, podendo ainda dificultar muito a colheita.

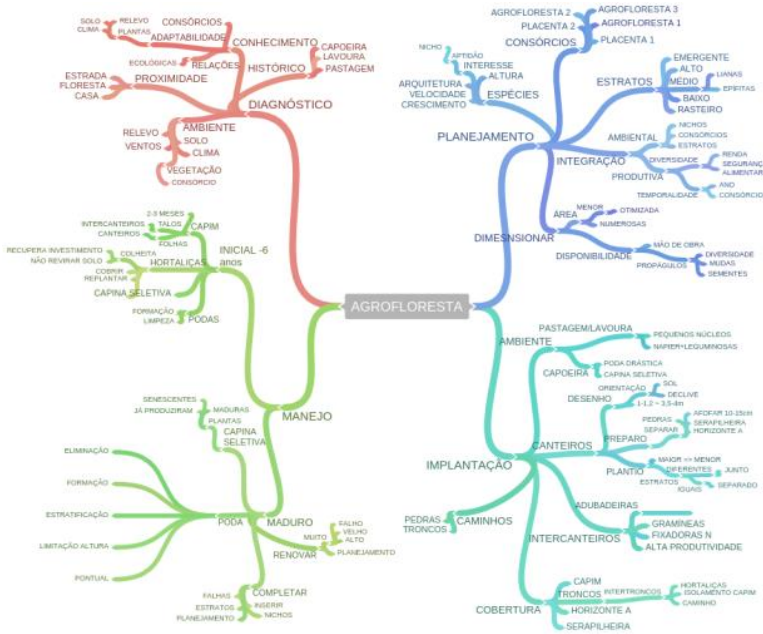

Figura 1. Mapa do Conhecimento Agroflorestal

$$
\text { Conclusões }
$$

A prática agroflorestal possui lógica e argumentos próprios baseados na observação e na experimentação no ambiente, que são diferentes dos da agricultura convencional. Apesar dos esforços de sistematização dessas experiências ainda há muito a ser realizado na área agroflorestal.

\section{Agradecimentos}

Agradece-se ao CNPq pela concessão de uma bolsa PIBIC ao primeiro autor.

\footnotetext{
${ }^{1}$ GÖTSCH, Ernst. Break-through in agriculture. AS-PTA, 1995

STEENBOCK, Walter; VEZZANI, Fabiane Machado.

Agrofloresta: aprendendo a produzir com a natureza. Curitiba,

Fabiane Machado Vezzani, 2013.

${ }^{3}$ THIOLLENT, Michel. Metodologia da pesquisa-ação. Ed. Cortez, 2011.

${ }^{4}$ BUZAN, Tony. Mapas mentais e sua elaboração. Editora Cultrix, 2005 .
} 